\title{
Re-examining the Status of the English Language in Anglophone Western Africa: A Comparative Study of Ghana and Nigeria
}

\author{
Oris Tom-Lawyer ${ }^{1}$, Michael Thomas ${ }^{2}$ \\ ${ }^{1}$ Department of English and Literary Studies, Igbinedion University, Okada, Edo State, Nigeria \\ ${ }^{2}$ School of Education, Liverpool John Moores University, Liverpool, United Kingdom \\ Correspondence: Oris Tom-Lawyer, Okada, Edo State, Nigeria. Tel: +234-8114-8968-41.
}

Received: Sep. 23, 2020

Accepted: Oct. 27, $2020 \quad$ Online Published: Nov. 1, 2020

doi:10.5430/elr.v9n4p6

URL: https://doi.org/10.5430/elr.v9n4p6

\begin{abstract}
This paper re-examines the status of English as a Second Language (ESL) in Anglophone Western Africa by comparing its use in Nigeria and Ghana. The research is based on the premise that the medium of instruction impacts the quality of education (Ferguson, 2013). The significance of the research is that it is one of the first studies to compare the standard of English language usage in the two countries to establish whether there is a positive link between the quality of education and the language of instruction (Williams, 2011). Predicated on a critical literature review, some of the issues and perspectives analysed include educational language policies, the attitude of students, the quality of teachers and the prospects of the language in the two countries. Findings indicate that the implementation of educational language policies remains an important challenge in the two countries, as there has been a falling standard of English usage (though Ghana has a higher standard of English language usage) and a dearth of English specialists. In identifying the factors that impact on the quality of education in Nigeria and Ghana, the paper concludes that English has significant potential in both countries, and if relevant strategies for its improvement are adopted, both countries will benefit from the socio-economic gains inherent in its adoption and use.
\end{abstract}

Keywords: Western Africa, Anglophone, English language, Ghana, Nigeria, status

\section{Introduction}

There are 7,117 spoken living languages in the world (Ethnologue, 2020). Of these languages, the English language has attained the status of a global language and been described as the language "on which the sun never sets" (Quirk, 1985; cited in Crystal, 2003, p.10). This is in sharp contrast to the way it was represented only a few decades previously as "vulgar ... immature, unpolished and limited in resources" (Baugh 1951; cited in Dada 2010, p. 435). English is now spoken by an estimated 1.2 billion inhabitants of the world (Ethnologue, 2019). It has its roots in the Germanic branch of the Indo-European family and it is the official or semi-official language of more than 42 countries in the world, compared to French with 27, Spanish with 20 and Arabic with 17 respectively (Genc \& Bada, 2010). These rankings capture the extent of its use as a global language. English has over 350 million native speakers (mainly based in the United Kingdom, Canada, New Zealand, the USA, Australia, South Africa and Ireland) and 430 million people (from countries such as India, the Philippines, Nigeria, Ghana, Zimbabwe, Zambia and Uganda), who speak it as a second language (Wil, 2015). In addition, in some countries, it is the preferred foreign language that people want to learn and Anglophone countries in the world are responsible for approximately $40 \%$ of the world's total GNP (Dutta, 2015). The United Kingdom earns more than $£ 2$ billion annually from teaching English as a Foreign Language (Ostler, 2018) and it is the language of business, medicine, technology and tourism. According to Cyrstal (2003, p. 3) a "language achieves a global status, when it develops a special role that is recognised in every country". English has been able to attain this goal in many countries mainly as a result of education. Almost all countries in the world have English in their curriculum; it is a pre-requisite for employment and communication; and it facilitates communication across borders (Ammon, 2001; Baker 2006; Graddol, 1997; cited in Pandarangga, 2015). In the view of Ulpepper (1997; cited in UK Essays, 2018), three criteria help to explain the emergence of a language as 'global' and the maintenance of its status: its political, military and economic power. This view corroborates the point noted by Crystal (2003), who argued that traditionally a language attains global status mainly as a result of military and political power. In this regard, as the primary language of the British Empire and United States of America, English has achieved this hegemonic status. However, the risks associated with the emergence of a global language have been noted; such as the 
death of minority languages, the manipulation of the language by native speakers and, given its ubiquity, it may make people reluctant to learn new languages and understand different cultures (Crystal, 2003).

The English language is a global phenomenon for several main reasons. Most importantly, presently its widespread use lends credence to its currency in the world. From its origin as an Anglo-Saxon language to its attainment as a native language, foreign language, second language and finally, a global language, its status has grown exponentially. Nevertheless, the language faces many challenges and has varying prospects in various contexts. The gap addresed by this research lies in a comparison of the falling standard of English language usage in Nigeria and Ghana and the need to establish a positive link between the quality of education and the language of instruction (Williams, 2011). English as a Second Language (ESL) is identified with countries that have adopted it as an official language (e.g. Anglophone countries). The aim of this study is to highlight the issues and perspectives associated with English as a Second Language in the two countries and recommend strategies for its effective integration and use. This study is based on the premise that the medium of instruction impacts the quality of education (Ferguson, 2013) as summed up in the words of Essien (2006; cited in Dada 2010, p.433):

If we want great artists-poets, playwrights, novelists, musicians, etc., we must make it possible for such talented people to acquire such facility in language as will enable them to express their imagination, feeling and insights freely. If we want great scientists and inventors, language must not inhibit those who have the innate abilities. If we want great politicians, economists, historians, linguists, etc., language should not stifle those who are gifted.

Arising from this context, five research questions will be investigated:

i. What are the differences in the language education policies of Ghana and Nigeria?

ii. What are the differences in the falling standard of English usage in Nigeria and Ghana?

iii. What are the attitudes of Nigerian and Ghanaian students toward English language learning?

iv. What are the differences in the quality of English language teachers in Nigeria and Ghana?

v. What are the future prospects of English in Nigeria and Ghana?

\section{Method}

The methodology adopted for the study is based on that of a critical literature review. Related to both countries, the main themes searched for were educational language policies, the status of English, attitudes toward English, teacher quality, and the prospects of English. Other secondary themes included teacher education, the political, social and economic benefits of English, English skills, and the prospects and challenges of teaching and learning English in both countries. Principally, peer reviewed journal articles were utilised. Blogs, newsmedia reports, monographs/books and theses/conference papers were also used to supplement the corpus of data. The indexes used were Academia.edu, Researchgate and Google Scholar.

The themes were selected based on their connection to the research questions. Table 1 provides a concise overview of the themes and their various sources. The first column shows the themes, followed by journals $(64 \%)$, books and monographs (14\%), blogs (4\%), news media and reports ( $8 \%$ ) and finally theses and conference papers (10\%). Journal articles constituted the majority of the sources reviewed given the prominence of academic research in the field. The books and monographs provided mostly factual information and quantitative data, while the theses and conference papers provided data on emergent research. Newsmedia and reports derived mainly from commercial organisations such as Euromonitor and EdQual provided an overivew of market trends. 
Table 1. Themes of the Study

\begin{tabular}{|c|c|c|c|c|c|}
\hline Themes & Journals & $\begin{array}{l}\text { Books and } \\
\text { Monographs }\end{array}$ & Blogs & $\begin{array}{l}\text { Newsmedia } \\
\text { Reports }\end{array}$ & $\begin{array}{l}\text { Theses and } \\
\text { Conference } \\
\text { Papers }\end{array}$ \\
\hline $\begin{array}{l}\text { Educational } \\
\text { Language Policies } \\
\text { in Nigeria and } \\
\text { Ghana }\end{array}$ & $\begin{array}{l}\text { Johnson \& Pratt, (2014); } \\
\text { Awuor, (2019); Tom-lawyer \& } \\
\text { Thomas (2019); Wornyo } \\
\text { (2015); Dada (2010); Quarcoo } \\
\text { (2014); Mahama (2012); } \\
\text { Erling, Adonolfi \& Hultgren } \\
\text { (2017); Ugal (2011); Adeyemi } \\
\text { \& Ajibade (2014); Obanya } \\
\text { (1998); Klu \& Ansre (2018); } \\
\text { Ansah (2014). }\end{array}$ & $\begin{array}{l}\text { Williams } \\
\text { (2001); } \\
\text { McIIwraith } \\
\text { (2013); } \\
\text { Okoroma } \\
\text { (2000). }\end{array}$ & & & $\begin{array}{l}\text { Owu-Ewie } \\
\text { (2006); } \\
\text { Ibekwe } \\
(2006)\end{array}$ \\
\hline $\begin{array}{l}\text { Status of English in } \\
\text { Nigeria and Ghana }\end{array}$ & $\begin{array}{l}\text { Owusu-Ansah (2006); } \\
\text { Ugwuanyi \& Omeje (2013); } \\
\text { Yusuf (2012). }\end{array}$ & $\begin{array}{l}\text { Berado (2011); } \\
\text { Mesthrie \& } \\
\text { Bhatt (2008); } \\
\text { Coleman } \\
\text { (2010); } \\
\text { Ethnologue } \\
\text { (2019). }\end{array}$ & $\begin{array}{l}\text { UK Essay } \\
(2018) \text {. }\end{array}$ & $\begin{array}{l}\text { Ostler (2018); } \\
\text { Dutta (2015). }\end{array}$ & $\begin{array}{l}\text { Tom-Lawyer } \\
\text { (2011). }\end{array}$ \\
\hline $\begin{array}{l}\text { Attitudes towards } \\
\text { English in Nigeria } \\
\text { and Ghana }\end{array}$ & $\begin{array}{l}\text { Sarfo (2012); Wayar (2017); } \\
\text { Ahmed (2015); Kolawole } \\
\text { (2019); Soku, Simpeh \& } \\
\text { Osafo-Adu (2011); Dako \& } \\
\text { Quarcoo (2017); Famogbiyele } \\
\text { (2019); Gardner, Magoret, } \\
\text { Tennant \& Mihic (2004). }\end{array}$ & Crystal, 2008. & & & $\begin{array}{l}\text { Mckinney } \\
\text { (2008). }\end{array}$ \\
\hline $\begin{array}{l}\text { Quality of English } \\
\text { Language Teachers } \\
\text { in Nigeria and } \\
\text { Ghana }\end{array}$ & $\begin{array}{l}\text { Asare \& Nti (2014); Akowuah, } \\
\text { Patnaik \& Kyei (2018); Nta, } \\
\text { Oden, Egbe \& Ebuta (2012); } \\
\text { Borti (2015); Taluah (2016); } \\
\text { Nite (2014); Daniseh (2018); } \\
\text { Oppong-Sekyere \& Akpalu } \\
\text { (2013); Nwanyanwu (2017); } \\
\text { Gwarjiko (2015); Fatiloro } \\
\text { (2015). }\end{array}$ & & & EdQual (2010). & $\begin{array}{l}\text { Tom-Lawyer } \\
(2015) \text {. }\end{array}$ \\
\hline $\begin{array}{l}\text { Propects of English } \\
\text { in Nigeria and } \\
\text { Ghana and } \\
\text { Prospects and } \\
\text { Challenges of } \\
\text { Teaching and } \\
\text { Learning English in } \\
\text { Nigeria and Ghana }\end{array}$ & $\begin{array}{l}\text { Morris (1998); Amua- Sekyi } \\
\text { (2005); Njoku (2017); } \\
\text { Muhammad, Ya'u, Aliyu \& } \\
\text { Hasan (2018); Danladi (2013); } \\
\text { Corlett (2013); Large (1996). } \\
\text { Adika (2012). }\end{array}$ & & $\begin{array}{l}\text { Docsity } \\
(2017) ; \\
\text { Ampere } \\
\text { Translations } \\
\text { (2018). }\end{array}$ & $\begin{array}{l}\text { Euromonitor } \\
(2010) ; \\
\text { European } \\
\text { Union }(2020) ; \\
\text { Common } \\
\text { wealth } \\
\text { Secretariat } \\
(2020) \text {. }\end{array}$ & \\
\hline $\begin{array}{l}\text { Languages in } \\
\text { Nigeria and Ghana }\end{array}$ & $\begin{array}{l}\text { The World Fact Book (2020); } \\
\text { Ethnologue (2020). }\end{array}$ & & & & \\
\hline English Skills & & & & & $\begin{array}{l}\text { Powell- } \\
\text { Davies } \\
(2015)\end{array}$ \\
\hline $\begin{array}{l}\text { Ghanaian English } \\
\text { and Nigerian } \\
\text { English }\end{array}$ & $\begin{array}{l}\text { Bobda (2000); } \\
\text { Nwoko (2016); Okoro (1986); } \\
\text { Brosnahan (1958). }\end{array}$ & $\begin{array}{l}\text { Huber \& Dako } \\
(2008) ; \text { Alo \& } \\
\text { Mesthrie } \\
(2000) \text {. }\end{array}$ & & $\begin{array}{l}\text { GhanaWeb } \\
\text { (2008). }\end{array}$ & $\begin{array}{l}\text { Bismarck } \\
(2014) ; \\
\text { Suglo } \\
\text { (2014). }\end{array}$ \\
\hline $\begin{array}{l}\text { Standard of } \\
\text { English Usage in } \\
\text { Nigeria and Ghana }\end{array}$ & $\begin{array}{l}\text { Amuzu \& Asinyor (2016); } \\
\text { Okoro (2017); Akeredolu-Ale } \\
\text { (2007); Amua-Sekyi (2005); } \\
\text { Sa'ad \& Usman (2014); } \\
\text { Amoakohene (2017); Mireku- } \\
\text { Gyimah (2014). }\end{array}$ & & & & \\
\hline
\end{tabular}




\section{Background}

Most of the indigenous languages in the world are in Africa (30\%) and Asia (32\%); these languages account for two thirds of all the languages in the world (Ethnologue, 2020). In Africa, there are 24 Anglophone countries. Most of them are former British colonies; Eritrea and Rwanda are former Italian colonies (Abeni, 2018). In Western Africa there are five former English colonies: Ghana, Nigeria, the Gambia, Liberia and Sierra Leone. Nigeria and Ghana are two of the most significant countries in this category; Nigeria is the most populous nation in Africa and Ghana was the first country in the region to gain independence. In the Western African region, English can be traced to the repartitioning of Africa at the end of World War II (Crystal, 2003). The repartitioning saw the emergence of Ghana and Nigeria as British colonies and English later took root in both countries. Ghana and Nigeria achieved independence in 1957 and 1960 respectively and their indigenous governments adopted English as the official language shortly thereafter; the policy has not been without educational challenges, however, as Williams (2011, p.40) has argued:

African politicians do not seem to have fully understood the difficulties of conducting state education in a language that few learners, and not all teachers, have mastered, nor have they understood the advantages of educating learners in their own languages.

This is a point of consideration for policy makers and educational stakeholders. The multi-lingual nature of the two countries has "given English the task of acting as a 'link' or neutral language" (Coleman, 2010, p.13).

Arising from the influence of the Niger River, the name 'Nigeria' was coined by Flora Shaw, the future wife of the British colonial administrator Lord Lugard in 1897. Today it has a population of 214028 302, with over 500 indigenous languages. The major ethnic groups in Nigeria are the Yoruba (15.5\%), Hausa (30\%), Igbo (15.2\%), Fulani (6\%), Tiv (2.4\%), Kanuri/Beriberi (2.4\%), Ibibio (1.8\%), Ijaw/Izon (1.8\%); a further $24.7 \%$ consists of less popular languages (World FactBook, 2020). The three major tribes in Nigeria are the Yoruba, Igbo and Hausa.

In contrast, Ghana means 'Warrior King' in the Soninke language (Worldatlas, 2020) and it has a population of 29340 248. The major ethnic groups in the country are the Akan (47.5\%), Mole-Dagbon (16.6\%), Ewe (13.9\%), Ga-Dangme (7.4\%), Gurma 5.7 \%, Guan 3.7\%, Grusi 2.55, and Mande 1.1\% (World FactBook, 2020). The major tribes in Ghana are the Akan, Nzema, Ewe, Ga, Dagaare and Dagbani (Adika, 2012). Both Nigeria and Ghana use English in governmental administration, especially for trade, commerce, and the judiciary.

Table 2. A Comparison of the Demographics of Nigeria and Ghana

\begin{tabular}{|c|c|c|c|c|}
\hline Country & Population & $\begin{array}{l}\text { Indigenous } \\
\text { Languages }\end{array}$ & Official Language & Major Groups \\
\hline Ghana & 29340248 & 50 & English & $\begin{array}{l}\text { Akan } 47.5 \% \text {, } \\
\text { Mole-Dagbon } \\
16.6 \% \text {, Ewe } \\
13.9 \% \text {, Ga- } \\
\text { Dangme } 7.4 \% \text {, } \\
\text { Gurma } 5.7 \% \text {, Guan } \\
3.7 \% \text {, Grusi } 2.5 \% \text {, } \\
\text { Mande } 1.1 \% \text {, } \\
\text { Other } 1.45 \% \text {. }\end{array}$ \\
\hline Nigeria & 214028302 & $500+$ & English & $\begin{array}{l}\text { Yoruba } 15.5 \% \text {, } \\
\text { Hausa } 30 \% \text {, Igbo } \\
15.2 \% \text {, Fulani } 6 \% \text {, } \\
\text { Tiv } 2.4 \% \text {, Kanuri/ } \\
\text { Beriberi } 2.4 \% \text {, } \\
\text { Ibibio } 1.8 \% \text {, } \\
\text { Ijaw/Izon } 1.8 \% \\
\text { and Other } 24.7 \%\end{array}$ \\
\hline
\end{tabular}

Source: World FactBook 2020

In summarising the colonial experience in Western Africa, Obanya (1998) noted the following key points:

- The British government made provision for the teaching of English at all levels of education, though the first three years entailed learning through an indigenous language. 
- The British recognised the notion of English as a Second Language based on their past experiences in World War II.

- The British adapted educational materials to suit African contexts.

- In Western Africa, teaching was allowed in languages such as Hausa, Igbo, Ga, and Ewe, etc.

- English was used as a reference point in the teaching of indigenous languages.

In this respect, the British pursued a more liberal system of education compared to the French policy in countries such as Guinea, Niger and Senegal.

\section{Data Analysis and Discussion}

\subsection{What Are the Differences in the Language Education Policies of Nigeria and Ghana?}

Eduational language policy is also known as language education policy or language-in-education and language policy in education (Johnson \& Pratt, 2014). Language policy in education stipulates the use of educational languages at various levels of education (Awuor, 2019). They are usually initiated by governments and they dictate the languages to be used in education (Adapted Okoroma, 2000). Language policy is a volatile issue in any multi-lingual society as sections of a society are prone to feel marginalised by the speakers of major languages. The complexity of a language policy becomes more intricate when the official language of a country is different from its indigenous languages (OwuEwe, 2006). A language policy gives preference to some languages to be used as mediums of education. According to Ibekwe (2006), the medium of instruction can mar or make the schooling process ineffective: "The factors that determine language education policies in Western Africa are the multilingual nature of the countries, the attitude of their governments, the legacy of their colonial masters and the complex nature of the requirements of a modern society" (Bamgbose, 1991 cited in Tom-Lawyer \& Thomas, 2019, p.88).

The highest status a language can attain is to be used as a medium of education and this decision is usually made at the national policy level for strategic political reasons. Indeed, as Wornyo (2015) has asserted, Western African elites use educational language policies to perpetuate their tenure in government. For a child to receive high quality education, the medium of instruction needs to be a familiar language, otherwise the child will not achieve his/her full potential. Teachers who impart knowledge are also expected to be proficient in the language. Two important functions of English in Nigeria and Ghana are that a) it serves as the language of education based on the clear assumption that there is a substantive connection between English and the quality of education (Ibekwe, 2006) and b) it also acts as a unifying factor in the countries (Anyidoho \& Kropp Dakubu 2008; cited in Quarcoo 2014; Odebunmi, 2005; Tom-Lawyer, 2011). Three types of language policies are endoglossic (concerned with the promotion of an indeginuous language), exoglossic (this promotes an imperial language) and mixed policies (the promotion of imperial and indigenous policies) (Rui, 1995; Cobarrubias, 1983; cited in Dada, 2010). To explore the importance of these categories, the place of language learning in the education policies of Nigeria and Ghana will now be examined in more detail.

\subsubsection{Ghana}

Any account of the rise of English in education policies in Ghana, according to Quarcoo (2014), needs to recognise the efforts of the Christian missionaries in the country, such as the Bremen, the Basel and the Wesleyan missionaries, who introduced different indigenous languages to Ghana as a medium for education in the nineteenth century. However, it was the Phelps-Stokes Committee, which was established in 1922 to make recommendations on educational improvement (Anyidoho, 2018), that recommended the early introduction of English as a subject, while mother-tongue languages were used as mediums of instruction in lower primary schools. This system was implemented in the educational system of Ghana in 1925 (MacWilliam, 1969; Gbedemah, 1975; Dzamashie, 1988; cited in Quarcoo, 2014) and it marked the first provision of the use of indigenous languages in education (MacWilliam, 1969; Graham, 1971; Gbedemah, 1975 cited in Owu-Ewie, 2006). Following legislation, the language in education policy in Ghana included the alternation of indigenous language use at the lower primary level and the use of English from the fourth year. Presently, only ten languages are recognised for use in formal education (Mahama, 2012) as shown in Table 2. Research demonstrates that Western African elites deprive large parts of the population access to quality education through educational language policies of this type (Wornyo, 2015) and there is a growing awareness of the value of native languages in initial schooling by Ghanaians and the non-implementation of the policies, as teachers may not be aware of them (Erling, Adinolfi \& Hultgren, 2017).

\subsubsection{Nigeria}

Nigeria's educational policy places a firm emphasis on the use of educational languages (Ugal, 2011). Education language policies in Nigeria have continually involved the use of the mother tongue or language of environment at the 
lower primary school and English from the fourth year. The policy is contained in the National Policy on Education (1977). Obanya's (1998) research on the various reforms to the policy describes the benefits of Nigeria's approach to education as:

- The learning of a second Nigerian language at the secondary level apart from the mother tongue.

- There is an increase in the number of Nigerian languages taught in schools and learnt as mother tongues.

- Nigeria recognises three major languages: Hausa, Igbo and Yoruba.

On the other hand, research also indicates that private primary/secondary schools do not always effectively implement these policies (Adeyemi \& Ajibade, 2014) and several critiques of the policies have been identified by researchers (Fafunwa Foundation cited in Dada 2010).

Table 3. Educational Language Policies in Nigeria and Ghana

\begin{tabular}{|c|c|c|c|}
\hline Year & Ghana & Year & Nigeria \\
\hline $1925-1957$ & $\begin{array}{l}\text { The Ghanaian language } \\
\text { was used as a means of } \\
\text { instruction in the first three } \\
\text { years. }\end{array}$ & 1927 & $\begin{array}{l}\text { Indigenous languages } \\
\text { should be used as the } \\
\text { medium of instruction in } \\
\text { lower primary schools. }\end{array}$ \\
\hline $1957-1966$ & English only policy. & & \\
\hline 1967-1969 & $\begin{array}{l}\text { Ghanaian language used } \\
\text { only in primary school. }\end{array}$ & 1977 & $\begin{array}{l}\text { The medium of } \\
\text { instruction will be the } \\
\text { mother tongue or } \\
\text { language of environment } \\
\text { and later English. }\end{array}$ \\
\hline $1970-1973$ & $\begin{array}{l}\text { The Ghanaian language is } \\
\text { used in the first four years } \\
\text { of primary school. }\end{array}$ & 1981 & $\begin{array}{l}\text { The medium of } \\
\text { instruction will initially } \\
\text { be the mother tongue or } \\
\text { language of envionment } \\
\text { and later English. }\end{array}$ \\
\hline 1974-2002 (Sept) & $\begin{array}{l}\text { The Ghanaian language is } \\
\text { used in the first three years } \\
\text { of primary school. }\end{array}$ & 1998 & $\begin{array}{l}\text { The medium of } \\
\text { instruction for lower } \\
\text { primary would be the } \\
\text { language of the } \\
\text { environment. }\end{array}$ \\
\hline $2002-2006$ & English only policy. & 2004 & $\begin{array}{l}\text { The medium of } \\
\text { instruction will be the } \\
\text { language of environment } \\
\text { in the first three years. }\end{array}$ \\
\hline 2008 & $\begin{array}{l}\text { The Ghanaian language is } \\
\text { used in the first three years } \\
\text { of primary school. }\end{array}$ & & \\
\hline
\end{tabular}

Sources: Musa (2010, cited in Ibrahiim \& Gwandu, 2016); Owu-Ewie (2006); Ibrahim and Gwandu (2016); National Policy on Education (1998).

\subsubsection{Comparisons}

A comparison of the policies shows that Ghana has an erratic system in terms of the role of English in education policies, while Nigeria has maintained a more consistent approach. Nigeria adopted the language of environment/the mother tongue policy, while Ghana recognises the use of ten native languages (a majority language in each region) in formal schooling (Erling, Adinolfi \& Hultgren, 2017). Ghana adopted an English only policy, while Nigeria has chosen to implement it only in urban areas rather than nationwide. Ghana and Nigeria face a significant challenge in implementing the policies in urban areas as elite members of the population prefer to have their children taught in English from kindergarten onwards. Neither of the countries have developed most of their languages for formal schooling (Owu-Ewie, 2006). However, overall, Ghana has had more educational language policies than Nigeria. 
In summary, it is necessary to note that policy makers and stakeholders need to formulate education language policy based on research-informed approaches that seek to understand the process of implementation. If the policies are wellformulated but not properly implemented, it will lead to poor academic performance (Klu \& Ansre, 2018). In addition, a poor mastery of the language of instruction will adversely affect performance in other school subjects (Dada, 2010). In other words, "this means that success in education at all levels depends to a very large extent on the individual's proficiency in the language of instruction" (Ministry of Education, Science and Sports Teaching Syllabus for English Language September 2007; cited in Ansah 2014, p.5). Again, lack of proficiency in the native languages inhibits proficiency in English (Lewelling, 1991; cited in Owu-Ewie, 2006) and is often due to the fact that the foundation for English are not well-established in the early years of primary schooling, and as a result students do not always perform well in English later in the school system (Owu-Ewie, 2006). Therefore, it can be concluded that language diversity and educational language policies promote underachievement in schools (Ibekwe, 2006).

\subsection{What Are the Differences in the Falling Standards of English Usage in Nigeria and Ghana?}

\subsubsection{New Englishes}

Varieties of English have developed due to improvements in digital communications in the global world and the diverse nature of these varieties has produced new forms of English (Berado, 2011). The term 'World Englishes' was introduced by Braj Kachru in 1984 to describe the varieties of English in the world. The argument by Grieve (1964; cited in Nwoko, 2016, p. 84) that "If English is to be an effective means of communication in Africa ... it is essential that it adapts itself so as to be able to express African concepts", this justifies the relevance of Nigerian and Ghanaian Englishes. English as a native language has varieties such as British English (Standard), American English and Canadian English. English as a Second Language (ESL) possesses varieties such as Ghananian English, Nigerian English, Indian English and Ugandian English. This process has been one clear consequence of contact between English and various indigenous languages (Mahama, 2012) in former British colonies. These varieties are "often not based on old or standard English but rather on more local contexts" (Berado, 2011, p. 10). Therefore, these second language varieties may be considered 'standard' in their own contexts. However, speakers of the language do not have a positive attitude to the many different varieties, which are not standard (Frank 2000; cited in Berado, 2011). The native variations are referred to as 'old varieties', while the second language variations are 'new Englishes' (Kachru, 1982; cited in Berado, 2011). Nigerian and Ghanaian Englishes are new Englishes because they satisfy the following criteria as proposed by Platt, Weber and Ho (1984; cited in Berado, 2011): they have gone through development in their educational systems, they have also developed in non-English speaking environments, they perform a number of functions in the two countries, and they have distinctive features arising from their contact with local languages.

\subsubsection{Ghanaian English}

There has been an extensive exploration of Ghanaian English (Sey, 1973; Adjaye, 2005; Ngula, 2011 cited in Addika, 2012; Suglo, 2014; Bobda, 2000). Ghanians take pride in their English usage (Bobda, 2000) and their educational level is associated with the type of English spoken (Sey, 1973, cited in Mahama, 2012). However, secondary teachers and higher institutions in Ghana have consistently complained about the falling standard in English usage in the country (Mahama, 2012). One area where this has been apparent is the morphological and syntactic features of English as identified by Huber and Dako (2008) and shown in Figure 1. 
i. Verb Phrase: In this area, patterns of substitution, insertion and particle omission were noted.

a. Put off the stove before you leave.

b. He was charged for stealing a car.

Insertion: They requested for better conditions.

They were encouraged to voice out our grievances.

ii. Tense-aspect-modality

a. Substitution of past perfect for present perfect:

The Government will have to take sterner measures than it had hitherto done.

It has been established hundreds of years ago.

b. Auxiliaries: An order with please in British English is taken asa polite request in Ghanaian English:

I want some milk, please.

I want to eat, please.

iii. Agreement: Breakdown in Ghanaian English of Prominal Distinctions:

Her name is John.

When Mary called his mother, he was disgusted.

iv. Noun Phrase Structure: Omission of Articles:

Kofi Annang is () African representative in the United Nations - If Ghanaians talk about a public facility, an article is usually inserted.

v. Lexicon: Sorry as used to commiserate: Sorry on the death of your mother.

vi. Idiomatic Expression: He is not on seat. Presently, he is not in his office.

Figure 1. Morphological and syntactic features of English in Ghana as identified by Huber and Dako (2008)

More recent research has also been conducted on this area. Mahama (2012), for example, identified some common areas in which students commit errors and attempted to assign the sources of such errors: two reasons given related to the low quality of teachers and the non-availability of teaching resources. In addition, Amuzu and Amanyor (2016) considered the effect of school pidgin English on the written English of Ghanaian Students. He concluded that there was no causal link between speaking pidgin English and the errors of students in their essays. Rather, the link was traced to the mother tongue (L1) features of the students as there is a link between the mother-tongue feaures of students' grammar and their errors. Moreover, Bismarck (2014) noted the following errors: i). concord errors, ii). spelling errors, iii). preposition errors, iv). vocabulary and expression errors, v). article errors, and vi). other errors such as the incorrect use of apostrophes, capitalisation and idiomatic expresssions as well as incomplete sentences. He also argued that mother tongue inflence is one of the reasons for the low performance of students in English.

\subsubsection{Nigerian English}

The existence of Nigerian English has long been proved (Walsh, 1967; Fresco, 1967; Spencer, 1971 cited in Okoro, 1986). According to Nwoko (2016, p. 85) "Nigerian English means those words and expressions that have been so fossilized in Nigeria that they have ceased to be merely imperfectly learned British English and have now become part and parcel of the English language used in Nigeria". It also denotes the English variety spoken and written in Nigeria (Alo \& Mesthrie, 2004) and thus it is defined as a type of 'new English'. According to Okoro (2017), it has forms that are substandard and as a result Brosnahan $(1958$, p.99) has identified four levels of Nigerian English based on the level of education:

Level I: Pidgin: spoken by people who have no formal education. However, these days, even the highly educated use this language.

Level II: This is spoken by primary school certificate holders as well as attendees at such schools.

Level III: This is spoken by secondary school certificate holders and similar students. This level is associated with an increase in fluency, more vocabulary and the non-use of Level 1 pidgin.

Level IV: This is spoken by university graduates and embellished with some characteristics of Levels II and III. This 
level is close to standard English.

Level IV, which is closest to British English, is regarded as the acceptable medium. Some of the reasons behind substandard usage in Nigerian English are "interference, inadequate motivation, poor teaching and learning as a result of lack of facilities and crowded classrooms" (Okoro, 2017, p. 1). Factors that have led to the uniqueness of Nigerian English as identified by Alo and Mesthrie (2000) include:

i. The acquisition of English through the classroom.

ii. Cultural contact between indigenous languages and English.

iii. The high status attained by English alongside its sociolinguistic roles.

iv. The influence of regional features which are non-standard.

The morphological and syntactic features of Nigerian English as discussed by Alo and Mesthrie (2000) are shown in Figure 2.

a. Tense: with regard to tense, the forms noted were the use of unmarked verb forms for both present and simple past: Did they came yesterday? They did said it. When did they told you?

b. Regularisation of past endings: burst-bursted, forecast-forecasted, sight read, sight readed.

c. Lack of third person singular present tense: The boy come from Delta State. She drink garri every morning.

\section{d. Complementation:}

Infinitive without 'to'.

Make her () pay the price.

\section{e. Reduplication:}

Do it quick quick-very fast.

Run to the shop now now- immediately.

Figure 2. Morphological and syntactic features of Nigerian English as discussed by Alo and Mesthrie (2000)

The contributions made by other researchers, who examined the spoken/written English of Nigerian students, are examined in what follows. Okoro (1986), for example, sampled the written and spoken English of university students. He viewed the errors as cases of Nigerian English and concluded that the errors should be seen as a lack of competence in the language rather than as Nigerian English. Ugochukwu (2018) examined some non-existent words and phrase usages. He pointed out that the words and phrases were not/would never be accepted internationally. He corroborated the observation of Okoro (1986) by arguing that some people continue to regard the incorrect words and phrases as Nigerian English. Okoro (2017) investigated errors in the written English of junior secondary school students in the Eastern part of Nigeria. She identified the errors of the students and attributed them to "L1 transfer, intralingual factors and students' carelessness" (Okoro, 2017, p.73). Nigerian English was examined in order to explain the differences in grammatical lexical levels from Standard English and it was concluded that the British standard should be the norm.

\subsubsection{Comparison}

Ghanian and Nigerian English are characterised by 'non-standard usages' (Bismarck 2014; Amuzu \& Asinyor, 2016; Alo \& Mesthrie, 2000; Huber \& Dako, 2000; Okoro, 2017). Alo and Mesthrie (2000) demonstrate that Nigerians lack the knowledge of the basic structure of the language, while the study of Huber and Dako (2000) indicates that Ghanains have a higher standard of English language usage. In addition, there is a lot of mother tongue interference in Nigerian English. The maintenance of the closeness of Ghanaian English to British English and its intelligibility to the native speaker was noted by Huber and Dako (2000). The difference between Nigerian English and Ghanaian English is mostly observed in speech (Bamgbose, 1971; cited in Okoro, 2017). The different types of error observed in the two countries are similar (Okoro 2017; Bismarck 2014; Amuzu \& Asinyor, 2016).

Overall, several studies note that there has been a decrease in the standard of English usage in the two countries (Ghana web, 2008 \& Akeredolu-Ale, 2007). In Nigeria and Ghana, the abysmal failure of students (Amua-Sekyi, 2005; Sa'ad \& Usman, 2014) have been recorded. In Ghana, it has been noted that "performance in English Language, especially within the university setting has been described in various unpalatable terms to reflect concerns about its falling standard" (Mireku-Gyimah, 2014; cited Amoakohene 2017, p. 55). 


\subsection{What Are the Differences in the Attitudes of Nigerian and Ghanaian Students to English Language?}

The attitude of the learners of a language towards that language, its speakers and the functions of the language are the prime factors that determine the successful acquisition and learning of the language (Mckenzie, 2008; Spolsky, 1989; cited in Sarfo, 2012). If students are favourably disposed toward learning a language they will become proficient as they will be motivated to learn. However, a negative attitude is associated with difficulty in learning a language and will lead to fossilization. A positive attitude will benefit a second language learner, while a negative attitude will lower the rate of motivation and lead to lack of proficiency (Wayar, 2017). Crystal (2008) defines attitude as people's feelings concerning their language or other people's language. Therefore, several factors contribute to the attitudinal positivity or negativity toward a language. Interestingly, research shows that the positive and negative attitudes of a teacher toward students are associated with the success and failure of their students (Mckinney, 2008). Ahmed (2015, p.7) defines 'attitude' as:

the attitudes, which speakers of different languages or language varieties have toward each other's languages or their own language. Expressions of positive or negative feelings towards a language may reflect impressions of linguistic difficulty or simplicity, ease of difficulty of learning, degree of importance, elegance social status etc.

This definition demonstrates that language attitude to a great extent will determine the success/level of achievement in the learning/acquisition of a language. The importance of the knowledge of students' attitude towards learning cannot be overestimated. This in consequence will effectively equip the teacher to teach the language (Kolawole, 2019). The correct attitude towards learning a language is a pre-requisite for proficiency in a second language as motivation is a positive product of attitude (Kolawole, 2019). At this point it is worth reviewing research on the attitude of Ghanaian/Nigerian students in English language as this in turn impacts the quality of education.

\subsubsection{Attitude of Ghanaian Students Towards the English Language}

Most of the studies reviewed so far have provided similar results on the attitude of students towards English. Sarfo (2012), for example, concludes that there is a favourable attitude towards English among university students in Ghana, especially as English was viewed as a link to career opportunities. Other researchers such as Soku, Simpeh and OsafoAdu (2011) showed that female students possess a better attitude to the study of English than their male counterparts. In addition, Dako and Quarcoo (2017) concluded that Ghanaians have a positive attitude toward English because it is a 'gateway' to opportunities. However, Borti (20015) reports that Ghanaian Junior High School Students possess a negative attitude towards learning and particularly English language learning. In addition, Sey (1973 cited in Berardo, 2011) noted that the Ghanaian students would not be interested in using a local version of English.

\subsubsection{Attitude of Nigerian Students Towards the English Language}

Attitudes cannot be discussed without addressing the research on motivation and many studies have established a link between motivation and attitude in language learning (Gardner, Magoret, Tennant \& Mihic, 2004). The studies conducted in Nigeria are explicit on this point (Famogbiyele, 2017; Kolawole, 2019). Wayar (2017) examined gender-based attitudes of northern Nigerian students toward English and findings suggest that students had a positive attitude towards English and that they were motivated to learn the language; however, the females had a higher level of motivation. In the same vein, Famogbiyele (2017) examined the motivation and the attitudes of northern and southern geo-political Nigerian students towards English. His study revealed that the students had a positive attitude towards the language but lacked the motivation to apply it. However, Kolawole (2019) reported a negative attitude towards the language by junior secondary school students and intertwined it with factors such as peer pressure and poor study habits.

\subsubsection{Comparison}

In terms of a comparison, the students in the two countries have a positive attitude towards English. Researchers have noted that female students tend to have a better attitude towards the language than males (Wayar, 2017; Soku et al., 2011) The Nigerian reseachers identified how motivation is an important factor that works pari passu with attitudes (Famogbiyele, 2017; Kolawole, 2019). The positive attitude observed in the two countries may be connected to the status and fuctions of English as a Second Language (ESL). Therefore, a positive attitude should be accompanied by the correct levels of motivation. Finally, motivation in learning a language impacts the overall quality of education.

\subsection{What Are the Differences in the Quality of English Language Teachers in Ghana and Nigeria?}

The role of the teacher in the teaching and learning process is a complex one as the the actions of the teacher will be replicated in the attitudes of the students in their learning process; it has been asserted by Timperly, Wilson, Barrar and Fung (2007, p.xvii) that "Little is known about how teachers interpret the available understandings and utilise the 
particular skills offered during professional learning opportunities, or the consequent impact of these on teaching practice and student outcomes". This implies that pre-service and in-service training determine the profile and quality of teachers as well as the outcomes of student learning.

In this respect it is also important to note in addition, as Adegoke (2003; cited in Asare and Nti, 2014, p. 1), put it, that "Education is a condition for development and the teacher is the ultimate definer of its reality". The importance of this finding underpins the conclusion that the quality of education is majorly dependent on the medium of instruction in any society (Erling et al., 2017). To access quality education in Nigeria and Ghana, the acquisition and usage of English both play a major role (Akowuah, Patnaik \& Kyei, 2018). Indeed, the acquisition of language skills by students is an objective in most language curricula. This is to be achieved by students with the aid of teachers, who are expected to act as facilitators. In other words, the quality of teachers will to a large extent determine the positive achievement of students.

This section of the paper considers the teacher factor in the acquisition of English by students. The teacher factor relates to a "teacher's personality, training, language, language proficiency and teaching ability" (Anyawu, 2002; cited in Nta, Oden, Egbe \& Ebuta, 2012, p. 113). The teacher factor can also be seen in English language teaching methods adopted by teachers, teacher qualifications, the professional development of teachers (Akowuah et al., 2018), teachers' absenteeism and the skills and adequacy of teachers overall (Ayodele, 1998, Adenuga, 2002, Etsey 2005, Asikhia 2012 $\&$ Nta et al. 2012 cited in Tom-Lawyer, 2015). The Chief Examiner of the West African Examination Council (WAEC) in a report published in the Daily Graphic in Ghana in 2004 and 2006 asserted that teachers' poor knowledge of teaching methods is one of the factors responsible for students' low performance in English (Borti, 2015). Several other researchers have concurred with this point, reiterating that principally, the expertise of the teacher is a determinant of students' positive achievement (Villaume \& Brabham, 2003; in cited in Nta et al., 2012, p.113). The status of English in Ghana and Nigeria is important as it is the official language and plays several key roles in the two countries. The language is a medium of instruction and also a subject of study in both countries. It is learnt at all levels of the education system, which makes the problems associated with its teaching and learning interrelated. Principally, the auspiciousness or inauspciousness of Nigeria and Ghana's educational systems depends on effectively teaching, learning and English language usage (Poku, 2008). The positive achievement of students in other subjects is dependent on their mastery of English (Taulah, 2016). Learning a language successfully depends on the creativity, versatility and resourcefulness of the teacher. According to Borti $(2015$, p. 25), "Thus, the students will gain acceptable proficiency levels if their teachers expose them to the necessary and adequate methodology, and communicative activities". However, critics have argued that the teacher factor alone should not determine the the success or failure in learning a language (Williams, 1981; cited in Nite, 2012).

On the other hand, Boardi et al (1981; cited in Nite 2014) maintain that one of the weak points of present language teaching programmes is the emphasis on teaching methods rather than the content of the subject. Presently, there are several issues associated with the teaching and learning of the language with regard to the teachers of the language; they have been seen as unqualified, while students lack a serious attitude to learning and they feel that they already possess the required knowledge in the language (Taulah, 2016). Overall, there is the need for an improvement in the oral and written English skills of Sub-Saharan students as western Anglophone countries and teacher education need overhauling (Akowuah et al., 2018).

\subsubsection{Ghana}

Research conducted in Ghana has revealed that among other intervening factors, poor teaching methods and ineffective continuining professional development for teachers contribute to the underachievement of students in English (Akowuah et al., 2018). This perspective lends credence to the fact that the quality of the teacher plays a major role in the achievement of the students. To corroborate this point further, Dansieh (2018) examined the challenges of students in oral English in Upper West Ghana. His research demonstrated that students as well as teachers face challenges in English pronunciation, and recommended further consideration of relevant training for teachers in this specialised area. In the same vein, research conducted by EdQual (2010) on classroom practices in English and African languages on the point at which pupils switch the official language of instruction in Ghana and Tanzania, highlighted several important findings and suggestions. It was observed that students could not read their English textbooks. Moreover, pupils did not participate fully in L2 classrooms as they had little to contribute.

In analysing the situation, it was demonstrated that underachievement in African schools is partly related to language problems and that the low standard of English proficiency in Western African schools involving English as a language of instruction impedes the learning of pupils (Macdonald, 1993; Rubagumya, 2003; cited in EdQual, 2010). It was suggested that a more effective initial teacher education programme for teachers was required and that professional 
development programmes for African and European language teachers, as well as readable textbooks for pupils, should be provided. In research to identify supplementary factors that contribute to the low performance of pupils in English, it has also been shown that the teachers of the language were not specialists and that this resulted in poor teaching methods as well as difficulty in teaching key concepts (Oppong-Sekyere, Oppong-Sekyere \& Akpalu, 2013). Similarly, a study conducted to compare classroom practices in Ghana and India revealed that a teacher-centered (textbook focused) approach was dominant as teachers spoke most of the time and students listened (Erling et al., 2017).

Therefore, the quality of teachers who teach English in West African schools is very important, especially if quality education is a key priority. In a study on Teacher Education in Ghana: A Contemporary Synopsis and Matters Arising, it was noted that "the dominant pedagogical stance (in teacher training schools) remains one where trainees are largely regarded as 'empty vessels,' with little knowledge or experience of teaching" (Lewin \& Stuart, 2003; cited Asare and Nti 2014, p.6). This research demonstrates that supplying quality teachers is a pre-requisite for the achievement of the overall goal of quality education in Ghana.

\subsubsection{Nigeria}

In Nigeria, researchers have identified the need for quality training for pre-service teachers; this was the view of Nta et al. (2012), who examined the adequacy of the course content of the English programme in a university in Nigeria. This research pointed out that a revision of the curriculum content was in progress and advocated for the continuous development of teachers. Moreover, Nwanyanwu (2017) investigated issues relating to the teaching of English in a multicultural setting; findings suggested that English was not effectively taught in secondary schools or universities (IATEFL ESP SIG, 2013 cited in Nwanyanwu, 2017). In addition, the teachers lacked the basic skills needed for teaching young L2 learners (Fernandes, 2013; cited in Nwanyanwu, 2017). Moreover, a shortage of English professional teachers was reported. Again, Gwarjiko (2015) investigated the perceptions of English second language learners' teachers and interestingly reported a dearth of professional English teachers and the handling of the subject by non-English specialists.

The problem of English language specialists is a major one as Fatiloro (2015) has also identified. The consequence is that the teaching of English is often undertaken by non-English graduates. In this respect it is important to note that Nigerian universities do not award TESOL degrees (Teaching English to Speakers of Other Languages) at undergraduate level. Addressing this challenge is fundamental as it will equip teachers with an understanding of the pedagogies required for the teaching of the language.

\subsubsection{Comparison}

A comparison of the research studies mentioned above shows that the quality of teachers in the two countries is a significant challenge in their education systems. The non-availability of English specialists in both countries has consequently given rise to the use of non-English specialists in classrooms. The award of TESOL degrees in Ghana is a significant positive point, while it is not available at the undergraduate level in Nigerian universities. It is recommended that education stakeholders in the country should reflect on this issue as it impacts the teaching and learning of English, and consider awarding TESOL Degrees at the undergraduate level.

\subsection{What Are the prospects of English in Nigeria and Ghana?}

Both Ghana and Nigeria are multilingual nations as they have various indigenous languages. In addition, bilingual education is practised in both countries via the transition model, specifically the early transition exit model, which aids the transition from local languages to English within grades one to three (Erling et al., 2017). The choice of English as an official language in the two countries was made at independence by the elite groups. As the role of English in the two countries remains fundamental in the decades that followed, its exclusion now would lead to a myriad of problems. While Erling et al., (2017) asserted that the choice of an instructional language is difficult in both countries, Morris (1998) noted that the importance of English cannot be underestimated as some children even use it as their first language. English perfoms specifically the same functions in the two countries to varying degrees and continues to be associated with prestige, pride, respect, success, and development, and is perceived as a ticket for progression and advancement in life.

\subsubsection{Ghana}

In Ghana, English performs several different roles. A research study conducted to determine the functions of English in contemporary Ghanian society reports that Ghanaians associate the language with prestige, confidence, success and better lifestyles. In addition, the use of English in Ghana is seen as being technical as the language is used mostly for formal purposes rather than informal occasions such as traditional ceremonies (Morris, 1998). In addition, he also indicated that Ghanaians have different languages for different settings and that the replacement of English in Ghana by a local language 
would lead to problems. Furthermore, another study by Amua-Sekyi (2005) on the problems and prospects of English in Ghana, asserts that teachers, parents, the media, administrators and even the West African Examination Council (WAEC) are responsible for the transmission of incorrect English (common mistakes) to their students. He also points out that the assumption that a non-specialist could teach English is unacceptable. In sum, English in Ghana has developed a formidable role and its replacement would present challenges on many different levels.

\subsubsection{Nigeria}

In Nigeria, English also plays a similarly multifaceted role. Njoku's (2017) research on English, the Nigerian Educational System and human development found that English is an instructional language as well as a tool for the development of human beings. Njoku contends that as an instructional language, English is instrumental to the attainment of educational benefits for Nigerians. These benefits include better prospects, higher incentives, increased productivity, and higher living standards. In addition, English plays a unifying role as well as providing opportunities for interaction and investments, thereby linking the world to Nigeria. Related to this, Muhammad, Ya'u, Aliyu and Hassan (2018) examined the role of English in Nigeria with regard to social, political, economical and environmental development. They argued that the relevance of any third world country is tied to its usage of English as this fosters individual growth and national development. In addition, it confers prestige on the elites as it is a ticket to academic attainments and opportunities for a good job.

Another researcher, Danladi (2013) investigated the role English performs with the relation to its influence as an instructional language, and its political, social and academic benefits. In particular, English is used to coordinate social activities. Politically, the multi-ethnic nature of Nigeria bequeaths on English the symbol of unity. Finally, English is described as having a "gatekeeping" role (Danladi, 2013, p.7) and is the first language of preference for children.

\subsubsection{The Prospects of English in Ghana and Nigeria}

The future challenges of English as a Second Language in both countries have been explored extensively by several researchers (Danladi, 2013; Muhammad, Ya'u, Aliyu \& Hassan, 2018; Ugwuanyi, 2013) and it is important to explore them through the lens of economics, the social dimension, and politics in the final section of the paper.

i. Economical: The benefits of English are due to the global status of the language. It is associated with better educational opportunities as possessing English abilities grants admission to Anglophone European universities (Ulfier, 2014) and their degrees possess a high status (Euromonitor, 2010). English has become a pre-requisite for competition on a global scale enabling people to compete with their counterparts internationally; thus possessing English skills gives access to better study opportunities (Powell-Davies, 2015). Furthermore, developing Anglophone countries attract increased Direct Foreign Investment from countries such as Britain and America, while the reverse is the case in less developed Francophone countries (Euromonitor, 2010). A credit pass in English is needed in both countries for the attainment of tertiary education. The West African Examinion Council (WAEC) is saddled with the responsibility of conducting examinations to ascertain the proficiency of students in English in the region. The certificates issued by the WAEC in the long run determine employment opportunities for graduates in both countries. The possession of excellent English skills gives access to employment in multinational organisations and research has shown that individuals with better English skills earn more incentives as English facilitates trade and employment opportunities between Nigeria and Ghana (Ulfier, 2014).

ii. Political: Language communicates the message of politics. Different speeches, political debates and interviews use English as a medium to achieve their goals; therefore, in Anglophone countries worldwide, English is the language and vehicle of politics (Corlett, 2013). English is the working language of the European Union which has an internal market of approximately 500 million consumers (European Union, 2020; Decsy, 1993; cited in Large, 1996). English was the language of colonialism; even though colonialism has been dismantled, English is the language of former British and American colonies. Finally, it is the language of the Commonwealth, an association comprising almost all former British colonies and as such, a political body that works towards the progress of member nations (Commonwealth Secretariat, 2020). Both Ghana and Nigeria operate a democratic form of government and as such persuasion is needed to attain and maintain political power. English is the languge of politics in Nigeria and Ghana and is used during political campaigns, newspaper editorials and in manifestoes (Docsity, 2017). English is the de facto language needed to influence the thoughts of electorates and is used to shape elections in the two countries (Ampere Translations, 2018; Phillipson, 1997).

iii. Social: According to Powell-Davies (2015), improvements in English skills can help to develop partnerships between the state owned and private enterprise that may lead to the supply of essential services, particularly to disadvantaged groups. The continued existence of English in the two countries will remain for a long time due to their 
multi-ethnic nature. English is also a symbol of unity in the two countries. The social advancement of Nigeria and Ghana is dependent on the continued use of English as minority tribes are very much aware of the issue of marginalisation. According to Yusuf (2012, p. 901) "English is used for phatic communion, ceremonial purpose[s], [as an] instrument of keeping records, information dissemination, self embodiment and thought among the various linguistic groups in Nigeria". While there is still some disagreement about the long term prospects of English in both countries (Danladi, 2013), it seems clear that English will be irreplaceable for a long time to come.

\section{Conclusion}

This paper has re-examined the status of English as a Second Language (ESL) in Western Africa by comparing standards of language use in Ghana and Nigeria. Findings from the research studies reviewed have indicated that some of the factors that affect the effectiveness of the language in the two countries include their educational policies, the falling standard of English language usage, the quality of teachers and the unmotivated attitude of Ghanaian and Nigerian students. Based on these conclusions, the paper reiterates the following recommendations by previous researchers:

i) Research shows that Africa is the only continent that permits initial school learning in a foreign language (Quane \& Glanz, 2010; cited in Williams, 2011).

ii) Research demonstrates that the early transition to English may affect the proficiency of students in English (Cummins 1976; Toukomaa and Skutnabb-Kangas 1977; cited in Owu-Ewie, 2006).

iii) The concrete development of indigenous languages alongside English is a necessity. Funds are needed for the development and protection of indigenous languages (Owu-Ewie, 2006).

iv) "Other languages (including African languages or European languages) should only be used as a medium of instruction after learners have developed academic reading and writing competency in the language they are familiar with, and after they have gained a sufficient level of academic proficiency in the second language through studying that language as a subject. This principal recommendation applies to all languages that are not a learner's mother tongue. When the language education model chosen requires transition from one language of instruction to another, that transition should be gradual and not sudden" (The Jubal Language- in Education Conference 2012, cited in Mcllwraith, 2013, p. 8).

\subsection{Recommendations for Ghana}

It is necessary to emphasise that language-in-education fluctuations are consequent upon "the lack of political will on the part of government and educational stakeholders to priortise education" (Bamgbose, 1976, 2008; cited in Klu \& Ansre, 2018, p. 600). The interest of all stakeholders should be considered in the formation of language-in-education policies. One of the reasons for the falling standard of English usage is the inadequate teaching and learning of the subject in schools (Mireku-Gyimah, 2014). This is an area that must be addressed for effective results. The fall in the standard of education has been attributed to students' poor levels of comprehension in the subject (Owusu-Ansah, 2006) and this shows that the language of instruction impacts the overall quality of eduation (Williams, 2011)

\subsection{Recommendations for Nigeria}

In Nigeria, a curriculum for TESOL degrees at the undergraduate level would help to improve teaching and training standards in the language. The government, stakeholders, teachers and students all have a role to play in a strategy aimed at improving the standard of English language provision and usage in the country. The government, stakeholders, teachers, and students should assume their responsibilities for the improvement of the language in the two countries. Accordingly, the findings of this review align with the statement of Ugwanyi and Omeje (2013, p. 37) that "the most pressing issue in our education system is to correct the falling standard of the English Language". Finally, it is evident that English is fundamental to the development of Nigeria and Ghana and if the correct strategies are adopted, both countries stand to reap educational, social, political and economic benefits at the national and international level. 


\section{References}

Adeyemi, B., \& Ajibade, A. (2014). Degree of implementationlanguage provisions in primary and secondary schools in Southwestern Nigeria. World Journal of Education, 4(4). https://doi.org/10.5430/wje.v4n4p92

Ahmed, S. (2015). Attitude towards English language learning among EFL learners at UMSKAL. Journal of Education and Practice, 6, 1-12.

Akeredol-Ale, B. (2007). Good English for what? Learners' motivation as a factor in declining learners' performance in English Langauge acquisition and use in Nigerian schools. Changing English: Studies in Culture and Education, 14, 231-245. https://doi.org/10.1080/13586840701443065

Akowuah, J., Patnaik, S \& Kyei, E. (2015). Challenges in African classrooms: A case study of the Ghanaian context: Research in Humanities and Social Sciences, 5(4), 28-36. https://doi.org/10.1080/23311886.2018.1503577

Alo, M., \& Mesthrie, R. (2004) Nigerian English: Morphology and syntax. In B. Kortmann, K.A.R. Burridge, K., Mesthrie, R., Schneider \& C. Upton (Eds), A handbook of varieties of English: Vol 2. Morphology and Syntax (pp. 813-827). Berlin: Mouton de Gruyter.

Amoakohene, B (2017). Error analysis of students essays: A case of first year students in the university health and allied sciences. Internet Journal of Higher Education, 6(4), 54-68. https://doi.org/10.5430/ijhe.v6n4p54

Amua-Sekyi, E. (2005). English as a second language in Ghana and English Language teaching: Problems and prospects. The Oguaa Educator, 12(1), 24-30.

Amuzu, E., \& Asinyor, E. (2016). Errors on Ghanaian students' written English: Is speaking school Pidgin English the cause? GJDS, 13(2), 48-65. https://doi.org/10.4314/gjds.v13i2.3

Asare, K., \& Nti, S. (2014). Teacher education in Ghana: A contemporary synopsis and matters arising. Sage Open, 4(2), 128. https://doi.org/10.1177\%2F2158244014529781

Awuor, Q. (2019). Language policy in education: The practicality of its implementation and the way Forward. Journal of Language, Technology \& Entrepreneurship in Africa, 10(1).

Berardo, A. (2011). New Englishes in a new world: A brief introduction to Canadian English. Roma: Aracne.

Bobda, S. (2000). The uniqueness of Ghanaian English pronunciation in West Africa. Studies in the Linguistic Sciences, 30(2), 185-195. http://hdl.handle.net/2142/9659

Borti, A. (2015). Challenges in Afircan classrooms: A case study of the Ghanaian context. Research in Humanities and Social Sciences, 5(4), 28-36.

Brosnahan, L. (1958). English in Southern Nigeria, English Studies, 36(1-6), 97-110. https://doi.org/10.1080/00138385808597010

Coleman, H. (2012). The English language in development. London: British Council.

Crystal, D. (2003). English as a global language. Cambridge: Cambridge University Press.

Crystal, D. (2008). A dictionary of linguistics and phonetics. London: Penguin. https://doi.org/10.1002/9781444302776

Dada, S., (2010). Language policies and planning in Nigeria: Issues and perspectives. Journal of the Linguistic Association of Nigeria, 13(2).

Danladi, S. (2013). Language policy: Nigeria and the role of English in the $21^{\text {st }}$ Century. European Scientific Journal, 9(17). https://doi.org/10.19044/esj.2013.v9n17p\%25p

Dansieh, S. (2018). Teaching oral English in an ESL setting: Some challenges observed by teachers in Upper-West Ghana. International Journal of English Linguistics, 8(6). https://doi.org/10.5539/ijel.v8n6p172

EdQual (2010). Language of instruction and quality of learning in Tanzania and Ghana. London: EdQual.

Erling, E., Adinolfi, L., \& Hultgren, A. (2017). Multilingual classrooms: Opportunities and challenges for English medium instruction in low middle income. Reading: British Council.

Euromonitor (2010). English quantitative indicators: Cameroon, Nigeria, Rwanda, Bangladesh, Pakistan. London: British Council. 
Famogbiyele, O. (2017). Nigerian senior secondary school students' attitudes' attitude and motivation toward English language learning: Case study of northern and southern geo-political zones. Asian Journal of Education Research, 5(4), 9-29.

Fatilori, F. (2015). Tackling the challenges of teaching English as a Second Language (ESL). IOSR Journal of Research Methods in Education, 5(2).

Genc, B., \& Bada, E. (2010). English as a world language in Academic writing. Reading Matrix, 10(2), 142-151.

Gordon, R., \& Grimes, B. (2019). Ethnologue: Languages of the world. London: SIL International.

Gwarjiko, U. (2015). English as a second language teachers' perspections' of new English language Curriculum in Niger state, Nigeria. European Journal of of Language Studies, 2(2), 12-21.

Huber, M., \& Dako, K. (2018). Ghanaian English: Morphologyand syntax. In R. Mesthrie (Ed.), Varieties of English: Africa, South and Southeast (pp. 368-380). Berlin: de Gruyter.

Ibekwe, J. (2006). Education language policy in Nigeria. Unpublished Doctoral Thesis. University of Connecticut.

Johnson, D. C., \& Pratt, K. L. (2014). Educational language policy and planning. The Encyclopedia of Applied Linguistics. https://doi.org/10.1002/9781405198431.wbeal1416

Klu and Ansre, M. (2018). An overview of the language education policy in Ghana: Emerging issues. Medwell Journals: The Social Sciences, 13, 569-601.

Kolawole, P. O. (2019). Attitude of Junior secondary school students toward the study of English language their academic achievement. International Journal of Social Politics and Humanities.

Mahama, E. (2012). English and its implications for academic writing: A case study of English on the Navrongo campus of University of Development Studies. Ghana Research on Humanities and Social Sciences, 2(11), 5663.

Mckinney, R. (2005). Teacher attitude towards English language learners. Unpublished PhD dissertation. University of Tennessee.

Mireku-Gyimah, P. B. (2014). Analysis of errors in the English of final year university students: A case study at the university of mines and technology. Journal of ELT and Applied Linguistics (JELTAC), 2(4), 23-46.

National Foreign Assessment Center (2020). The world fact book. Washington: Central Intelligence Agency.

Njoku, J. (2017). English Language, the Nigerian education system and human development. Journal of Arts and Humanities, 18(2), 211. https://doi.org/10.4314/ujah.v18i2.12

Nta, E., Oden, S., Egbe, E., \& Ebuta, C. (2012). Optimising students' performance in English through quality teacher education. Journal of Education and Practice, 3(9).

Nwoko, C. (2016). Domesticationof the English language in Nigeria: An examination of morphosyntactic trends in Nigerian English (NGE). International Journal of English Language Teaching, 4(5), 83-91.

Obanya, P. (1998). Language education in Africa: Lessons for and from Nigerian Faunwa Foundation Internet Journal of Education. Retrieved from http//www. fafuwa foundationtripod.com.

Okoro, O. (2017). Nigerian English usage and the tyranny of faculty analogy III. California Linguistic Notes, 41(1), 26-42.

Okoroma, N. (2000). The perspectives of educational management, planning and policy analyisis. London: Morison Publishers.

Oppong-Sekyere, D., Oppong-Sekyere, F., \& Akpalu, M. (2013). Some factors influencing the academic performance of junior high school pupils in English Language: A case of Assin North municipality, Ghana. International Journal of English Language and Literature, 4(5), 26-31.

Owu-Ewie, C. (2006). The language policy of education in Ghana: A critical look at the English-only language policy of education. In J. Muganeet et al. (Eds.), Selected Proceedings of the $35^{\text {th }}$ Annual Comference in African linguistics (pp. 76-85). Somerville, MA: Cascadilla Proceedings Project.

Powell-Davies, P. (2015). The social and economic case for developing English skills. Cairo: British Council.

Quarcoo, M. (2014). Language policy and language education in Ghana: A reality or illusion? Winsconsin Journal, $4(5), 49-59$. 
Sa'ad, T. U., \& Umar, R. (2014). The causes of poor performance in English language among senior secondary students in Dutse state, Nigeria. IOSR Journal of Research and Method in Education (IOSR-JRME), 4(5), 41-47. https://doi.org/10.9790/7388-04564147

Sarfo, E. (2012). Ghanaian University students' attitude towards English. International Review of Socia Sciences and Humanities, 4(1), 86-99.

Suglo, I. (2014). A comparative study of some phonological features as heard in some Ghanaian and Nigerian students speaking English. Unpublished bachelor's thesis. University of Ghana.

Timperly, H., Wilson, A., Parrar, H., \& Fung, I. (2007). Teacher professional learning and development. Retrieved http://counts.edcentre.govt.nz/goto/BES

Tom-Lawyer, O. (2011). English Language: A symbol of national integration In democratization good governance and education. Lagos State University. University International Conference, $26^{\text {th }}-30^{\text {th }}$ July. Lagos: Wallex Prints, 8590.

Tom-Lawyer, O. (2015). An evaluation of the implementation of the English language in Nigeria Certificate in education curriculum: A case study of three colleges of education. Unpublished Ph.D Thesis. University of Central Lancashire.

Tom-Lawyer, O., \& Thomas, M. (2019). Re-evaluating the hegemony of the English language in Western Africa: A critical review of the research (2003 to 2018). International Journal of Applied Linguistics and English Literature, 8(5), 83-95. https://doi.org/10.7575/aiac.ijalel.v.8n.5p.83

Ugal, D (2011). Language teaching and language policy in Nigeria. Retrieved from https://doi.org/10.2139/ssrn.1896334

Ugwanyi, E., \& Omeje, C. (2013). Challenges in the use of English in Nigerian tertiary institutions in a globalising world. Journal of Law, Policy and Globalization, 19.

Wayar, B. (2017). Gender based attitudes of students towards English Language in Northern Nigeria. International Journal of Innovative Language, Literature \& Art Studies, 5(3), 7-17.

Williams, E. (2011). Language policy, policies and development in Africa. In H. Coleman (Ed.), Dreams and realities: Developing countries and English language. London: British Council Design.

Wornyo, A. (2015). Language policy debate in Ghana: A means of elite closure. Sociology Study, 5(8), 643-652. https://doi.org/10.17265/2159-5526/2015.08.005

\section{Copyrights}

Copyright for this article is retained by the author(s), with first publication rights granted to the journal.

This is an open-access article distributed under the terms and conditions of the Creative Commons Attribution license (http://creativecommons.org/licenses/by/4.0/). 